\title{
Sovereign Credit Rating Determinants of the EU Countries: The Role of the Euro Area Crisis and Its Legacy
}

\author{
Ewa Stawasz-Grabowska
}

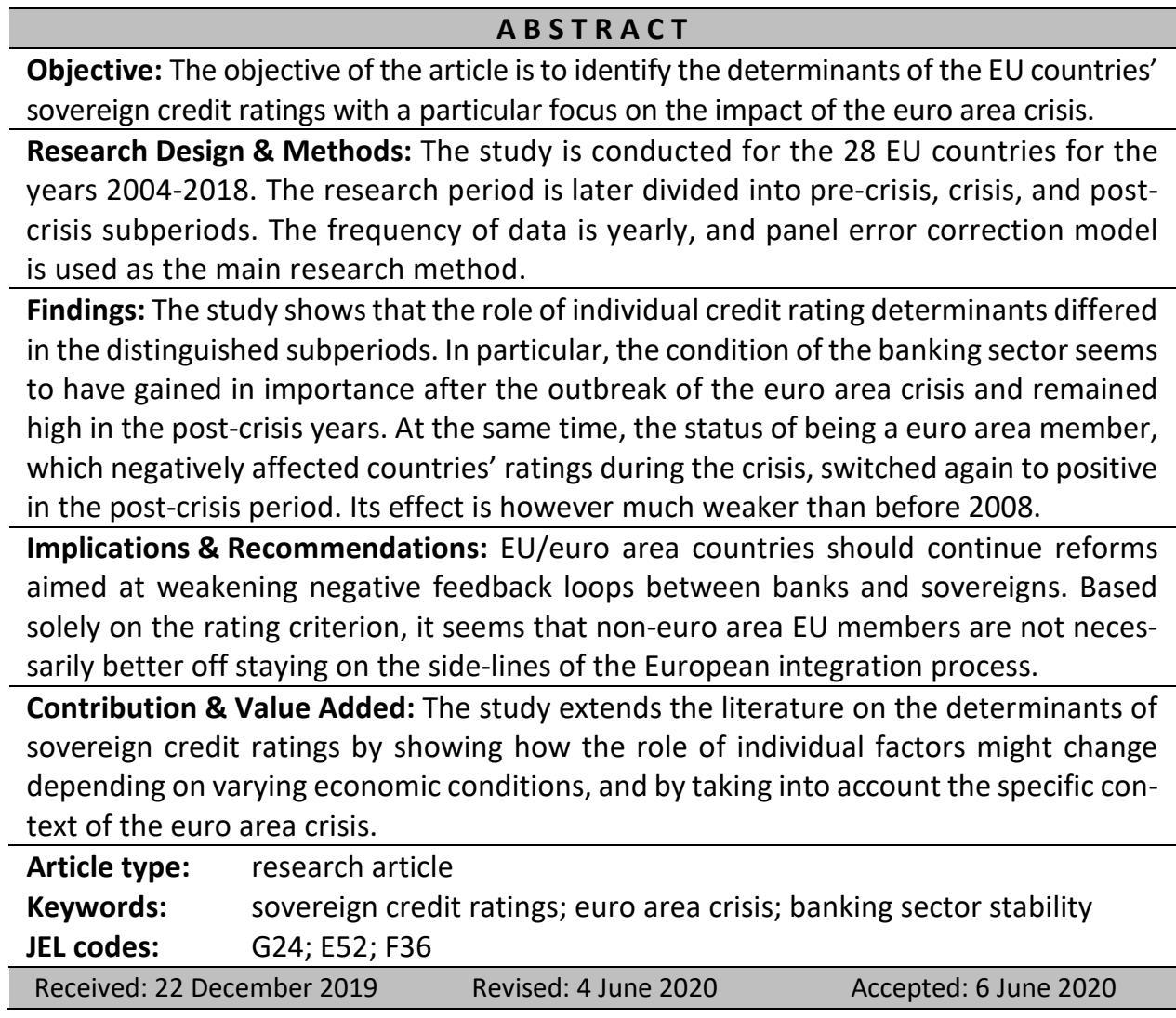

\section{Suggested citation:}

Stawasz-Grabowska, E. (2020). Sovereign Credit Rating Determinants of the EU Countries: The Role of the Euro Area Crisis and Its Legacy. Entrepreneurial Business and Economics Review, 8(2), 47-69. https://doi.org/10.15678/EBER.2020.080203 


\section{INTRODUCTION}

Sovereign credit ratings are used as measures of countries' ability and willingness to pay their debt obligations in full and on time. These assessments, which are provided by credit rating agencies (CRAs), have gained in importance over the past few decades due to financial integration and globalization of capital markets. Countries care about the best possible ratings as they largely determine the terms and extent of these countries' access to international financial markets. Moreover, the sovereign credit rating constitutes the benchmark for ratings given to various domestic entities such as banks and companies. This sovereign ceiling policy, as it is described in literature, has been found to be still applicable, especially towards emerging countries and distressed advanced economies, despite CRAs' declarations of its abolishment (cf. Luitel, Vanpée, \& De Moor, 2016). Finally, sovereign credit ratings are closely monitored by institutional investors, and in particular those that are legally bound to take into account the quality of assets when constructing investment portfolios.

In their assessments, CRAs use a wide set of quantitative and qualitative variables relating to different categories of sovereign credit risk (macroeconomic, institutional, political, etc.). And although these factors are revealed, the rating process still lacks transparency. In particular, there is no concrete knowledge of weights assigned to individual variables, nor their possible variability due to, for example, countries assessed (e.g. developed vs. developing economies) or prevailing economic conditions (e.g. crisis vs. non-crisis situation). Moreover, the final decisions on credit ratings might differ from what is implied by quantitative and qualitative analyses as they are subject to judgmental adjustments of credit rating committees (De Moor, Luitel, Sercu, \& Vanpée, 2018). Hence, numerous studies aim to identify and model the determinants of sovereign credit ratings.

This paper aims to identify the determinants of sovereign credit ratings of European Union (EU) countries, with a particular focus on the impact of the euro area crisis. The panel error correction model is used as the main research method. This study contributes to the existing literature in at least three ways, with a common denominator that is strongly embedded in the European context. First, next to economic and political aspects, which are traditionally considered in studies of this nature, the set of explanatory variables includes a factor reflecting the condition of a banking sector. This approach seems justified given the size and importance of the EU banking sector and the fallout of the euro area crisis, which was characterised by a negative feedback loop between banks and sovereigns. Surprisingly, the role of risk transfer from banks to sovereigns in shaping the latter's rating scores has been little explored, with only a handful of analyses solely devoted to EU economies. Taking the European perspective, this study gives particular attention to the level of non-performing loans (NPLs) as a measure of banking sector risk. The problem of NPLs was particularly acute in the euro area, so much so that its addressing was flagged as "one of the key priorities for ECB Banking Supervision since its inception," having been recognised as "critical to restoring confidence in the euro area banking system and the wider economy" (ECB, 2019).

Second, this study takes into account the specific course of the crisis in the European Economic and Monetary Union (EMU), which differed in comparison to the one observed in the United States and other parts of the world. More specifically, three subperiods are ana- 
lysed: pre-crisis (2004-2007), crisis (2008-2012), and post-crisis (2013-2018). The demarcation between the last two is the most distinctive as it relates to the European Central Bank's (ECB) acceptance of the role of lender of last resort in the second half of 2012 and the consequent reduction in stress in the EMU. By focusing on this periodization, this study will determine if and how the role of individual rating drivers changed under diverse economic conditions along with the changing architecture of the EU/euro area financial safety net.

Third, this study addresses the status of (non-)euro area members as an important determinant of the rating assessments of the EU countries. The findings offered by this study will add fresh insight to the existing literature on the costs and benefits of joining a common currency area such as the EMU. Research into this effort was initiated by Reusens and Croux (2017), who provide evidence that the effect of Eurozone membership switched from positive to negative after the outbreak of European debt crisis in 2009. This study aims to investigate whether there was another change after 2012 when the tensions in the EMU largely receded and the EU/euro area financial safety net underwent many changes related to its pre-crisis shape.

This paper is structured as follows. The introduction precedes a review of the literature on the determinants of sovereign credit ratings. The next section describes the data and explains the methodology used. Then, the empirical results are discussed and some political implications are offered. The main findings of the study are summarised in the concluding section.

\section{LITERATURE REVIEW}

There are a large number of studies that have aimed to identify the determinants of a country's credit rating. Different factors have been found to play a role depending on countries and time periods considered as well as estimation methods used. A chronological overview of existing literature allows us to distinguish the following lines of research.

The initial studies concentrated mainly on the role of quantitative macroeconomic variables in explaining sovereign credit ratings. In the seminal paper of Cantor and Packer (1996), six variables have been found statistically significant, i.e.: per capita income, GDP growth, inflation, external debt, level of economic development, and default history. Somewhat surprisingly, the authors did not identify any systematic relationship between ratings and fiscal stance. Subsequent studies confirmed to a large extent the findings of Cantor and Packer (1996) and/or pointed to a slightly larger explanatory power of external variables (cf. Monfort \& Mulder, 2000; Afonso, 2003; Bissoondoyal-Bheenick, 2005).

Over time, next to macroeconomic indicators, more and more attention was given to institutional and political factors as potential determinants of sovereign credit ratings. For example, Connolly (2007) shows that higher governmental corruption has a negative impact on sovereign rating scores. This finding particularly pertains to low-income countries with poor regulatory framework and those that have not been a former British colony (as the rule of English law is believed to provide an institutional framework, lessening corruption). The statistically significant effect of corruption has also been found by, among others, Mellios and Paget-Blanc (2006), Amstad and Packer (2015), and Teixeira, Silva, Ferreira, and Vieira (2018). Other authors provide evidence that the quality of institutions, which is often approximated by the six governance indicators reported by the World Bank, is an important driver of sovereign ratings (cf. Erdem \& Varli, 2014 or 
Ozturk, 2014). The findings of those studies should be of particular interest to developing economies, as they suggest that the rating gap with regard to developed countries can be narrowed through the enhancement of institutions. Further, the institutional strength of monetary authorities has also been found to play a role. For example, Montes and de Oliveira (2016) identify the introduction of inflation targeting as a very relevant factor enhancing sovereign creditworthiness assessment of CRAs. This is due to the fact that the adoption of this policy framework is associated with greater levels of accountability, transparency, and independence of a country's central bank, which should translate into a more effective monetary policy. Similarly, central bank independence turns out to be significant in the study of Soudis (2016).

A large number of research studies find different sets of sovereign rating determinants for different groups of countries. The level of the country's economic development is the most commonly used criterion of division. For example, Afonso (2003) finds that GDP per capita is the sole important economic variable when explaining credit ratings for developed economies. In turn, for developing economies, external debt turns out to be statistically significant. Similarly, Bissoondoyal-Bheenick (2005) concludes that GNP per capita and inflation play an important role for high-rated countries with a long financial stability history, while ratings of low-rated economies are additionally influenced by the current account balance and the level of foreign exchange reserves. In a study solely devoted to the euro area countries, Boumparis, Milas, and Panagiotidis (2017) show that GDP per capita is a major driver of high-rated countries. It follows that countries with high levels of GDP per capita take advantage of a kind of "protection" against potential downgrades. At the same time, low-rated countries are under the stronger influence of the unemployment rate, regulatory quality and competitiveness.

Membership in a given economic integration group is another commonly used criterion of division. For example, Chodnicka-Jaworska (2015) applies the following political divisions to a sample of 45 European economies: EU and non-UE countries, euro area and non-euro area members, CEE countries. Among other factors she finds that changes in GDP growth are of key importance for the credit rating assessment for countries remaining outside the EU. In another study, Reusens and Croux (2017) investigate the time varying weights attached by CRAs to different factors in their decision-making process over the years 2002-2015. One of their main findings is that after the outbreak of the European debt crisis, the effect of being a euro area member switched from positive to negative.

Some authors go one step further and devote their analyses to the issue of bias in the CRAs' rating of sovereign debt. A growing number of such studies, and particularly those carried out after the outbreak of the 2007/2008 global financial crisis, indicate the existence of such a phenomenon. For example, Gültekin-Karakaş, Hisarcıklılar, and Öztürk (2011) find that CRAs give higher ratings to developed economies regardless of their macroeconomic fundamentals. Tennant, Tracey, and King (2020) provide evidence of a statistical bias against poor countries, which entails that it is more difficult for them to get an upgrade for any given favourable changes in institutional and macroeconomic fundamentals. The results obtained by Reinhart (2002) and Reusens and Croux (2017) suggest that discrimination against developing economies might deepen after crises. The conclusions stemming from other studies imply that the US as well as countries which are close to the US in economic, geographical, and political terms receive higher ratings (cf. Yalta \& Yalta, 
2018; De Moor et al., 2018). In this context, Luitel et al. (2016) observe that American rating agencies favour countries that are in high voting coincidence with the US in the UN General Assembly. Conflicting results are provided by Ozturk (2014), who suggests that lower ratings of developing economies do not result from any discrimination on the side of CRAs, but rather from poor quality of their institutions. Similarly, Amstad and Packer (2015) identify no signs of bias against any groups of countries.

Analysis of the existing literature shows that financial sector stability has been rarely accounted for in research on the determinants of sovereign credit ratings. Surprisingly, this also pertains to a large number of analyses conducted after the outbreak of the 20072008 crisis. Among this scarce literature, Aktug, Nayar, and Vasconcellos (2013) - using a large set of advanced and developing economies - show that concentration in the banking sector and increased liquid reserves of the banking system are likely to exert a negative impact on ratings, while larger financial systems are associated with lower sovereign risk. Somewhat conflicting results were obtained by Sehgal, Mathur, Arora, and Gupta (2018) who conclude that because larger banking systems are more vulnerable to systemic risk, they are more likely to weigh on the country's rating.

Further, in a study devoted to the EU countries from 1999 through 2014, Brüha and Kočenda (2018) investigate the impact of various banking sector characteristics on four different indicators of sovereign risk, including credit ratings. They show that NPLs are the single most influential sector-specific variable, the increase of which is likely to adversely affect sovereign risk assessment. Boumparis, Milas, and Panagiotidis (2019), using a panel of 72 countries from 1998 through 2016, identify a feedback loop between sovereign credit ratings and banking risk factors. Finally, Chari, Garcés, Martínez, and Valenzuela (2019) investigate the relationship between financial fragility, global factors, and sovereign credit risk in a group of emerging market economies. They introduce a new metric of financial fragility, which computes the direct costs of bailing out the whole banking sector, and show that there is a negative correlation between the metric and sovereign credit ratings.

Based on the literature review, as well as accounting for the course of the crisis in the EMU and the changes introduced to the EU/euro area financial safety net since the crisis, the following hypotheses have been formulated.

H1: Next to the macroeconomic and institutional variables, the factors reflecting financial stability risk have additional explanatory power for sovereign ratings in the EU countries.

H2: Since the outbreak of the crisis, there has been an increase in the role of banking sector stability in explaining the sovereign ratings of the EU countries.

H3: When the financial safety net was enhanced, the status of euro area members regained positive effect on the sovereign ratings in the post-crisis years.

\section{MATERIAL AND METHODS}

The study is conducted for the $28 \mathrm{EU}$ countries, out of which 19 use the euro and 9 remain outside the common currency area, for the years 2004-2018 ${ }^{1}$. The lower boundary relates to the year of the largest EU enlargement, when 10 countries, mainly from Central and

\footnotetext{
${ }^{1}$ Since the research period ends in 2018, the United Kingdom is counted as an EU member.
} 
Eastern Europe, became the EU members. The choice of the upper boundary was conditional on the availability of data at the time of the study. The frequency of data is yearly. The study employs the rating classification of Standard \& Poor's (S\&P) to construct the dependent variable. A detailed description of the variables used in the study as well as research methodology is presented below.

\section{S\&P'S credit rating system and the dependent variable}

The credit rating industry is dominated by three big agencies, i.e. S\&P, Moody's, and Fitch Group. To generate the dependent variable, the credit rating decisions of S\&P will be used. The choice of this rating agency was dictated by the following considerations. First, S\&P has been found to be most active in making credit rating changes, which allows for obtaining a larger data set. Second, S\&P's ratings are known to precede those of the other two rating agencies. Third, they are less anticipated by market participants and therefore evoke a stronger market reaction (for all three arguments, cf. Gande \& Parsley, 2005; Christopher, Kim, \& Wu, 2012; Ballester \& González-Urteaga, 2017).

S\&P distinguishes four main credit rating scales: A, B, C, and D. "AAA" is the highest rating and indicates an obligor's "extremely strong capacity to meet its financial commitments". "SD" and " $D$ " are the lowest credit ratings. The first is assigned when an obligor is believed to have selectively defaulted on part of its financial obligations. An obligor rated " $D$ " is believed to fail to meet (substantially) all of its obligations in a timely manner. To differentiate among issuers within the rating categories, S\&P uses plus (+) and (-) signs. Those modifications are applied to ratings from "AA" to "CCC" categories 2 . Like in a number of previous studies, the ratings are transformed to a scale from 1 to 21 ("SD"/"D" to "AAA") as detailed in Table 1.

Furthermore, S\&P uses rating outlooks in its assessment of potential changes to longterm credit rating over the intermediate term (from six months to two years). In particular, an outlook can be positive, negative, or stable. To account for outlook changes, $1 / 3$ is added to (subtracted from) the numerical value assigned to a given rating in case of a positive (negative) outlook. That way, to give an example, a "BB" rating with a positive outlook will be transformed to 10 and $1 / 3$, while a "BB" rating with a negative outlook will be transformed to 9 and $2 / 3$.

Finally, unlike in many previous studies which take into account end-of-year observations, the rating variable for a given country in a given year is created as the average of numerically expressed ratings and outlooks assigned by S\&P for that country in that year. Such a construction of the dependent variable allows for the inclusion of all changes introduced by S\&P throughout the year ${ }^{3}$. S\&P's credit ratings and outlooks have been collected from Thomson Reuters Eikon database.

\footnotetext{
${ }^{2}$ Retrieved from https://www.standardandpoors.com/en_EU/web/guest/article/-/view/sourceld/504352 on November 11, 2019.

${ }^{3}$ For example, on 16 June 2017, S\&P changed its credit rating for Slovenia from A with positive outlook (set at that level in December 2016) to A+ with a stable outlook. The next revision took place only in 2018 . Thus, the value of 16 and $1 / 3$ is applied for the days between the beginning of 2017 and June, 152017 , and the value of 17 is applied for the days from June 16, 2017 till the end of 2017. Hence, the rating variable for Slovenia in 2017 is 16.70 , which is calculated as the average from daily data.
} 
Table 1. The linear transformation of S\&P's long-term issuer credit ratings

\begin{tabular}{|c|c|c|c|}
\hline Category & Rating description & Rating & Transformation \\
\hline \multirow{10}{*}{ 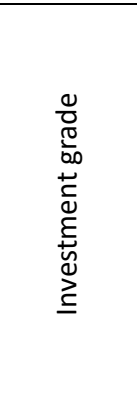 } & Prime & AAA & 21 \\
\hline & \multirow{3}{*}{ High grade } & AA+ & 20 \\
\hline & & $A A$ & 19 \\
\hline & & AA- & 18 \\
\hline & \multirow{3}{*}{ Upper medium grade } & $A+$ & 17 \\
\hline & & A & 16 \\
\hline & & A- & 15 \\
\hline & \multirow{3}{*}{ Lower medium grade } & $\mathrm{BBB}+$ & 14 \\
\hline & & BBB & 13 \\
\hline & & BBB- & 12 \\
\hline \multirow{11}{*}{ 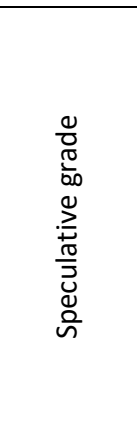 } & \multirow{3}{*}{ Non-investment grade speculative } & $\mathrm{BB}+$ & 11 \\
\hline & & BB & 10 \\
\hline & & BB- & 9 \\
\hline & \multirow{3}{*}{ Highly speculative } & $\mathrm{B}+$ & 8 \\
\hline & & $B$ & 7 \\
\hline & & B- & 6 \\
\hline & \multirow{3}{*}{ Substantial risks } & $\mathrm{CCC}+$ & 5 \\
\hline & & $\mathrm{CCC}$ & 4 \\
\hline & & CCC- & 3 \\
\hline & \begin{tabular}{|l} 
Extremely speculative \\
\end{tabular} & $\mathrm{CC}$ & 2 \\
\hline & In default/ in default with little prospect for recovery & $\mathrm{D} / \mathrm{SD}$ & 1 \\
\hline
\end{tabular}

Source: own elaboration based on https://countryeconomy.com/ratings; retrieved on November 9, 2019.

\section{Explanatory variables}

The set of explanatory variables consists of traditionally considered macroeconomic and institutional factors, as well as factors reflecting financial stability risk which are specific to the EU context and have been given little attention in prior research. Its construction was also dependent on data availability. The list of explanatory variables with their definitions, sources and expected sign of the effect on the credit rating are presented in Table 2.

In general, an improvement in macroeconomic fundamentals is expected to exert a positive impact on the dependent variable. More specifically, an increase in GDP growth, GDP per capita, investment, as well as an improvement in general government (GG) balance should be conducive to higher ratings, while an increase in GG debt, private debt, inflation, and unemployment is expected to work in the opposite direction. The impact of two external variables, i.e., the CA variable and the Openness variable, on the credit rating seems ambiguous. In the case of the former, on the one hand, current account $(C A)$ deficits might indicate a country's competitiveness problems. On the other hand, as the CA also reflects the difference between national savings and investment, a CA deficit might be indicative of a higher rate of investment and point to a highly productive and fast-growing economy ${ }^{4}$. Regarding the Openness variable, it

\footnotetext{
${ }^{4}$ Retrieved from https://www.imf.org/external/pubs/ft/fandd/basics/current.htm\#author on November 11, 2019.
} 
can be argued that countries that do not honour their payment obligations can be "punished" via disruptions in trade. Hence, higher openness should be conducive to lower sovereign risk. On the other hand, more open economies are more vulnerable to external shocks, which, in times of heightened stress, may increase their default risk (cf. Ramlall, 2016).

Referring to the institutional and qualitative factors, better governance and a higher level of economic sentiment are likely to exert a positive impact on the rating. When it comes to the Default history variable, a negative sign of the corresponding coefficient is expected since sovereigns that have defaulted on their debt in the recent past are considered riskier. Similar reasoning pertains to the Assistance variable. During the crisis, several EU countries were beneficiaries of financial assistance granted at the level of euro area/EU and - in most cases - the International Monetary Fund (IMF). As countries applying for such assistance most often experience serious market turbulences and loss of access to market sources of financing, a negative sign of the parameter estimate is expected. Finally, NPLs are used for assessing financial stability risk. They weigh on banks' profitability and limit their capacity to grant new loans, thus undermining future growth prospects. Hence, the predicted effect of the NPL variable on the rating is negative.

Table 3 presents some basic descriptive statistics. In the years 2004-2018 the median rating for all EU countries amounted to 17.00 , which corresponds to At. The lowest rating of 2.91 was observed in Greece in 2012. The maximum value of 21.00 was reached by a dozen countries, though only Denmark, Germany, Luxembourg, and Sweden retained the triple-A rating over the whole period considered. Moreover, the mean rating of the euro area countries is higher than the one of non-euro area EU members. Nonetheless, that difference has clearly narrowed since the outbreak of the crisis (cf. Figure 1).

Table 3 also shows that the EU countries were marked by substantial heterogeneity in wealth per capita and other macroeconomic variables. The median GDP per capita (PPP-based) was 32743.24 USD. The minimum value of 12150.07 USD was obtained for the poorest country, Bulgaria, in 2004, while the maximum value of 98537.42 USD belonged to the richest country, Luxembourg, in 2007.

Among qualitative and institutional indicators, the Governance variable ranged from -0.01 to 1.96 . Both boundaries were recorded in 2004 - the lowest in Romania and the highest in Finland. In general, higher values of that variable were observed in the euro area, which was particularly evident in the years preceding the crisis. The Default history variable adopts the value of one in the case of Greece and Cyprus from 2012 and 2013 onwards, respectively. The Assistance variable takes on the value of one in the case of five euro area countries (Greece, Ireland, Portugal, Spain, and Cyprus) as well as three (at that time) non-euro area EU members (Hungary, Latvia, and Romania), all of which benefited from different forms of official financial aid during the crisis.

Finally, the distribution of the NPL variable exhibits positive skewness. The problem of NPLs was particularly evident in the peripheral euro area countries, specifically Cyprus, Greece, Italy, and Ireland. The maximum value of $47.75 \%$ was observed in Cyprus in 2015. The countries with the lowest ratios of NPLs were Luxembourg, Finland, and Sweden. 
Table 2. Explanatory variables: definitions, sources, and the expected sign of their impact on credit ratings

\begin{tabular}{|c|c|c|c|}
\hline Variable & Definition & Source & Sign \\
\hline GDP growth & Real GDP growth rate & Eurostat & + \\
\hline GDP per capita & $\begin{array}{l}\text { Gross domestic product per capita, constant prices (PPP, } \\
\text { international dollars) }\end{array}$ & $\begin{array}{l}\text { WEO Database } \\
\text { October } 2019 \\
\end{array}$ & + \\
\hline GG balance & General government surplus/deficit (\% of GDP) & Eurostat & + \\
\hline GG debt & General government debt (\% of GDP) & Eurostat & - \\
\hline Private debt & Private sector debt, consolidated (\% of GDP) & Eurostat & - \\
\hline Inflation & HICP inflation rate & Eurostat & - \\
\hline Investment & Gross fixed capital formation (\% of GDP) & Eurostat & + \\
\hline Unemployment & Unemployment rate & Eurostat & - \\
\hline CA & Current account balance (\% of GDP) & $\begin{array}{l}\text { Eurostat, WEO } \\
\text { Database } \\
\text { October } 2019 \\
\end{array}$ & $+/-$ \\
\hline Openness & $\begin{array}{l}\text { Sum of exports and imports of goods and services (\% of } \\
\text { GDP) }\end{array}$ & World Bank & $+/-$ \\
\hline Default history & $\begin{array}{l}\text { Binary variable adopting the value of } 1 \text { if a country has } \\
\text { defaulted on its debt in the past; } 0 \text { otherwise }{ }^{a}\end{array}$ & Moody's (2017) & - \\
\hline Governance & $\begin{array}{l}\text { The mean of } 6 \text { indices of the World Bank reflecting } \\
\text { different dimensions of governance: voice and } \\
\text { accountability, political stability, government } \\
\text { effectiveness, regulatory quality, rule of law, control of } \\
\text { corruption. The mean might adopt values from the range } \\
-2.5 \text { (weak governance) to } 2.5 \text { (strong governance). }\end{array}$ & $\begin{array}{l}\text { World Bank and } \\
\text { author's } \\
\text { calculations }\end{array}$ & + \\
\hline ESI & Economic Sentiment Indicator & Eurostat & + \\
\hline Assistance & $\begin{array}{l}\text { Binary variable adopting the value of } 1 \text { in the years when } \\
\text { a given country received financial assistance from the } \\
\text { ESM, the EFSF, the EFSM }{ }^{b} \text {, the EU balance of payments } \\
\text { assistance facility and/ or the IMF; } 0 \text { otherwise }\end{array}$ & $\begin{array}{l}\text { EU Commission- } \\
\text { State Aid } \\
\text { Database }\end{array}$ & - \\
\hline NPL & Bank non-performing loans to gross loans (\%) & $\begin{array}{l}\text { World Bank, } \\
\text { FRED }\end{array}$ & - \\
\hline
\end{tabular}

a If the country defaulted on its debt after 2004, 1 is assigned to the year of the default and to subsequent years.

${ }^{\mathrm{b}}$ ESM, EFSF, EFSM stand for European Stability Mechanism, European Financial Stability Facility, and European Financial Stabilisation Mechanism respectively.

Source: own study.

\section{Econometric model}

The relationship between the sovereign ratings and their determinants have been modelled with the use of different econometric techniques. Due to the adopted character of the dependent variable, two main approaches can be identified. The early studies employed linear regression techniques that assume the cardinality of the sovereign ratings (cf. Cantor \& Packer, 1996; Afonso, 2003; Connolly, 2007). Over time, this approach came under criticism, as more and more authors questioned the assumption of an equal distance between any two neighbouring categories of rating. The example often used is the difference between $\mathrm{BB}+$ and $\mathrm{BBB}-$-, when the grade changes from speculative to investment one, and the difference between $A A+$ and $A A A$. To address this controversy, a large 
Table 3. Descriptive statistics

\begin{tabular}{|l|c|r|r|r|r|r|r|r|}
\hline \multicolumn{1}{|c|}{ Variable } & N & Mean & Median & \multicolumn{1}{c|}{ Max. } & Min. & Std. Dev. & Skewness & Kurtosis \\
\hline Rating & 420 & 16.65 & 17.00 & 21.00 & 2.91 & 3.93 & -0.62 & 2.75 \\
\hline GDP growth & 420 & 2.23 & 2.40 & 25.20 & -14.80 & 3.72 & -0.31 & 8.90 \\
\hline GDP per capita & 420 & 34566.95 & 32743.24 & 98537.42 & 12150.07 & 14887.72 & 2.05 & 9.05 \\
\hline GG balance & 420 & -2.57 & -2.40 & 5.10 & -32.10 & 3.61 & -1.80 & 13.55 \\
\hline GG debt & 420 & 60.24 & 54.05 & 181.20 & 3.80 & 34.89 & 0.87 & 3.88 \\
\hline Private debt & 420 & 141.69 & 124.50 & 352.80 & 33.60 & 68.77 & 0.95 & 3.44 \\
\hline Inflation & 420 & 2.18 & 2.00 & 15.30 & -1.70 & 2.11 & 1.84 & 9.62 \\
\hline Investment & 420 & 21.91 & 21.60 & 37.30 & 11.10 & 4.11 & 0.70 & 4.68 \\
\hline Unemployment & 420 & 8.89 & 7.80 & 27.70 & 2.30 & 4.33 & 1.68 & 6.31 \\
\hline CA & 420 & -0.86 & -0.60 & 11.80 & -23.90 & 5.91 & -0.60 & 3.81 \\
\hline Openness & 420 & 121.13 & 103.22 & 416.39 & 45.61 & 67.85 & 1.94 & 7.49 \\
\hline Default history & 420 & 0.03 & 0.00 & 1.00 & 0.00 & 0.17 & 5.42 & 30.34 \\
\hline Governance & 420 & 1.06 & 1.03 & 1.96 & -0.01 & 0.49 & -0.10 & 2.08 \\
\hline ESI & 416 & 100.32 & 101.63 & 118.41 & 72.18 & 9.20 & -0.66 & 3.01 \\
\hline Assistance & 420 & 0.08 & 0.00 & 1.00 & 0.00 & 0.27 & 3.13 & 10.81 \\
\hline NPL & 416 & 6.27 & 3.82 & 47.75 & 0.10 & 7.42 & 2.73 & 9.36 \\
\hline Soure: own calcula
\end{tabular}

Source: own calculations conducted in EViews.

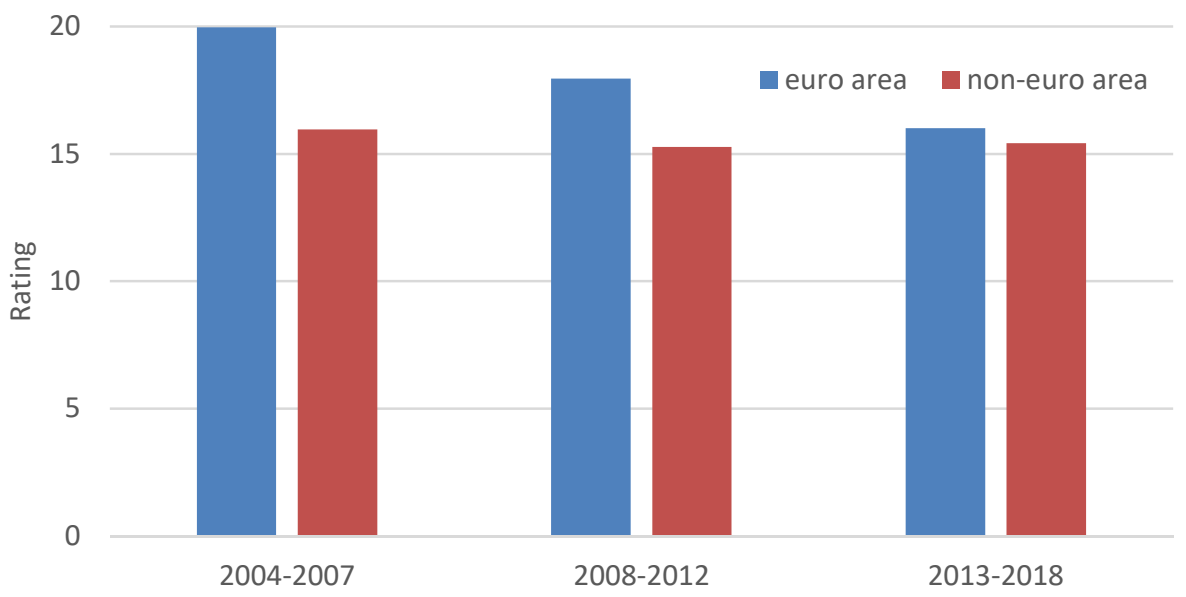

Figure 1. Sovereign credit ratings in the EU in 2004-2018: Euro area versus non-euro area The means for both groups of countries provide for their changing compositions. Source: own calculations based on Thomson Reuters Eikon data.

number of studies have applied an ordered probit model, which assumes that sovereign ratings represent an ordinal ranking of creditworthiness (cf. Bissoondoyal-Bheenick, 2005; Ozturk, 2014; Teixeira et al., 2018). Some authors have also used both estimation techniques for cross-checking the results (cf. Afonso, Gomes, \& Rother, 2010; Erdem \& Varli, 2014). The panel VAR (Boumparis et al., 2019) and Bayesian methods (Brůha \& Kočenda, 2018) are among the less frequently used estimation techniques. 
In this study, the construction of the dependent variable, as presented in the previous section, does not allow it to be treated in a discrete, ordinal nature. Taking this into account, panel cointegration techniques were chosen, as these allow for the identification of a long-run relationship between the ratings and the explanatory factors. These techniques are appropriate in the case of the presence of time series generated by stochastic processes integrated of order 1 . At the same time, to address the controversy regarding the construction of the dependent variable, a robustness check is conducted with the use of end-of-year ratings and ordered probit as an estimation technique. The results of this check are presented in the Appendix.

As a starting point, the following panel-data model illustrating a long-run relationship between the rating and the explanatory variables is considered:

where:

$$
y_{i t}=\alpha_{i}+\boldsymbol{\beta}^{T} \boldsymbol{x}_{i t}+u_{i t}, \quad i=1, \ldots, N \quad t=1, \ldots, T
$$

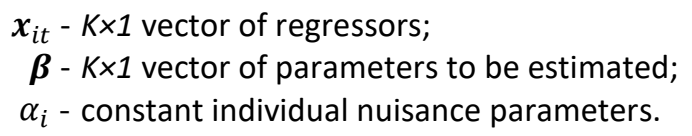

It is assumed that $u_{i t}$ are independent and identically distributed. However, in the case of a panel modelling framework, cross-sectional dependence may occur, which means that error terms $u_{i t}$ are correlated across sections. To verify whether the problem of cross-sectional dependence occurs, the test proposed by Pesaran (2004) is applied. In this test, the null hypothesis assumes that there is no correlation across sections. The appropriate statistic is defined as follows:

$$
C D=\sqrt{\frac{2 T}{N(N-1)}}\left(\sum_{i=1}^{N-1} \sum_{j=i+1}^{N} \hat{\rho}_{i j}\right)
$$

where:

$\hat{\rho}_{i j}$ - product-moment correlation coefficient of error terms.

If the null hypothesis of no cross-sectional dependence is valid, then $C D$ follows the standard normal distribution. Table 4 presents the results of testing for cross-sectional dependence.

Table 4. Testing for cross-sectional dependence in panel model

\begin{tabular}{|c|c|}
\hline Statistic & p-value \\
\hline 7.98 & 0.000 \\
\hline
\end{tabular}

Source: own calculations conducted in Stata.

The results indicate that the problem of cross-sectional dependence exists and the second-generation panel techniques should be used. The Pesaran test for the presence of a unit root is conducted (cf. Pesaran, 2007). The results of the Pesaran unit root test are presented in Table 5. The results indicate that most of the variables are integrated of order 1. This implies that the panel cointegration methods can be used to identify long-run relationships among the variables. Private debt is the only variable that is integrated of order 2 and therefore will not be used in the final specification. 
Table 5. Testing of order of integration for variables using Pesaran panel unit root test in the case of cross-sectional dependence

\begin{tabular}{|l|c|c|c|c|c|}
\hline \multirow{2}{*}{ Variable } & \multicolumn{2}{c|}{ Level } & \multicolumn{2}{c|}{ First difference } & \multirow{2}{*}{ Decision } \\
\cline { 2 - 5 } & Statistic & p-value & Statistic & p-value & \\
\hline Ratinga & 0.584 & 0.720 & -1.770 & 0.038 & $\mathrm{I}(1)$ \\
\hline GDP per capitab & 0.266 & 0.605 & -2.537 & 0.005 & $\mathrm{I}(1)$ \\
\hline GG balance & 0.555 & 0.710 & -4.678 & 0.000 & $\mathrm{I}(1)$ \\
\hline GG debt & 0.587 & 0.721 & -5.892 & 0.000 & $\mathrm{I}(1)$ \\
\hline Private debt ${ }^{\mathrm{c}}$ & 0.729 & 0.767 & 0.741 & 0.771 & $\mathrm{I}(2)$ \\
\hline Inflation & -2.634 & 0.004 & - & - & $\mathrm{I}(0)$ \\
\hline Investment & 1.392 & 0.918 & -3.706 & 0.000 & $\mathrm{I}(1)$ \\
\hline Unemployment & 0.515 & 0.697 & -2.140 & 0.016 & $\mathrm{I}(1)$ \\
\hline CA & -3.017 & 0.001 & - & - & $\mathrm{I}(0)$ \\
\hline Openness & 0.513 & 0.696 & -4.105 & 0.000 & $\mathrm{I}(1)$ \\
\hline Governance & 0.588 & 0.722 & -3.466 & 0.000 & $\mathrm{I}(1)$ \\
\hline ESI & -1.001 & 0.158 & -2.533 & 0.006 & $\mathrm{I}(1)$ \\
\hline NPL & -3.642 & 0.000 & - & - & $\mathrm{I}(0)$ \\
\hline
\end{tabular}

${ }^{a}$ As the Rating variable may adopt different values, it is treated as continuous.

${ }^{b}$ Due to the fact that GDP per capita is integrated of order 1, GDP growth is stationary.

c The results of testing the stationarity for second order differences are available upon request.

Source: own calculations conducted in Stata.

Due to the existence of cross-sectional dependence and the fact that most of the variables are integrated of order 1, the Westerlund (2007) test for panel cointegration is conducted. The test is based on the following data-generating process:

$$
\begin{gathered}
y_{i t}=\phi_{1 i}+\phi_{2 i} t+z_{i t}, \\
\boldsymbol{x}_{i t}=\boldsymbol{x}_{i t-1}+\boldsymbol{v}_{i t}, \quad i=1, \ldots, N \quad t=1, \ldots, T
\end{gathered}
$$

The scalar $y_{i t}$ consists of a deterministic part and stochastic part $z_{i t}$, which is modelled as:

$$
\lambda_{i}(L) \Delta z_{i t}=\lambda_{i}\left(z_{i t-1}-\boldsymbol{\beta}_{i}^{T} \boldsymbol{x}_{i t-1}\right)+\boldsymbol{\gamma}_{i}(L)^{T} \boldsymbol{v}_{i t}+e_{i t}
$$

where:

$$
\begin{aligned}
& \lambda_{i}(L)=1-\sum_{j=1}^{p_{i}} \lambda_{i j} L^{j} ; \\
& \gamma_{i}(L)=\sum_{j=0}^{p_{i}} \gamma_{i j} L^{j} .
\end{aligned}
$$

After substituting equation (3) into (5), the following panel error correction model is obtained:

where:

$$
\lambda_{i}(L) \Delta y_{i t}=\delta_{1 i}+\delta_{2 i} t+\lambda_{i}\left(y_{i t-1}-\boldsymbol{\beta}_{i}^{T} \boldsymbol{x}_{i t-1}\right)+\boldsymbol{\gamma}_{i}(L)^{T} \boldsymbol{v}_{i t}+e_{i t}
$$

$$
\begin{aligned}
& \delta_{1 i}=\lambda_{i}(1) \phi_{2 i}-\lambda_{i} \phi_{1 i}+\lambda_{i} \phi_{2 i} ; \\
& \delta_{2 i}=-\lambda_{i} \phi_{2 i} .
\end{aligned}
$$

The inclusion of a constant and/or deterministic trend depends on statistical significance. After testing the significance of deterministic components, the constant turned out to be significant and the trend was statistically insignificant. Based on equation (6), group mean statistics $\left(G_{\tau}, G_{\alpha}\right)$ and panel statistics $\left(P_{\tau}, P_{\alpha}\right)$ have been calculated. The results of testing panel cointegration are presented in Table 6 . 
The results of the Westerlund test indicate that cointegration exists in the presence of cross-sectional dependence. Therefore, the parameters of the panel error correction model are estimated. The results are presented in the next section.

Table 6. Results of testing panel cointegration with the use of the Westerlund test

\begin{tabular}{|c|c|c|}
\hline Statistic & Value of statistic & p-value \\
\hline$G_{\tau}$ & -3.450 & 0.000 \\
\hline$G_{\alpha}$ & -25.239 & 0.000 \\
\hline$P_{\tau}$ & -7.440 & 0.000 \\
\hline$P_{\alpha}$ & -2.886 & 0.000 \\
\hline
\end{tabular}

Source: own calculations conducted in Stata.

\section{RESULTS AND DISCUSSION}

Table 7 presents the results of the estimation of the cointegrating relation for the whole research period and all EU countries ${ }^{5}$. As a general-to-specific modelling strategy was adopted (Charemza \& Deadman, 1997), the table presents only parameter estimates that turned out to be statistically significant at 0.1 or lower level of significance.

Table 7. Estimates of the cointegrating relation

\begin{tabular}{|l|c|}
\hline \multicolumn{1}{|c|}{ Variable } & Estimate \\
\hline Rating $_{\mathrm{t}-1}$ & $-0.313^{* * *}(0.035)$ \\
\hline GDP per capita $\mathrm{t}_{\mathrm{t}-\mathrm{t}}$ & $0.001^{*}(0.001)$ \\
\hline Unemployment $\mathrm{t}-1$ & $-0.030^{*}(0.017)$ \\
\hline Assistance $\mathrm{t}_{\mathrm{t}}$ & $-0.572^{* * *}(0.200)$ \\
\hline Default history $\mathrm{t}-1^{\mathrm{a}}$ & $-2.297^{* * *}(0.374)$ \\
\hline GG debt $_{\mathrm{t}-1}$ & $-0.019^{* * *}(0.004)$ \\
\hline NPL $_{\mathrm{t}-1}$ & $-0.025^{* *}(0.011)$ \\
\hline Governance $_{\mathrm{t}-1}$ & $2.400^{* * *}(0.495)$ \\
\hline
\end{tabular}

Standard errors in parentheses.

$*, * *, * * *$ indicate statistical significance at the $0.1,0.05$, and 0.01 level, respectively.

Source: own calculations conducted in Stata.

After normalization, the long-run relation between credit ratings and other categories is as follows:

$$
\begin{aligned}
\text { Rating } & =0.003 G \text { DP per capita }-0.096 \text { Unemployment }-1.827 \text { Assistance } \\
& +7.668 \text { Governance }-0.061 G G \text { debt }-7.339 \text { Default history } \\
& -0.080 \mathrm{NPL}
\end{aligned}
$$

As it can be seen, a large number of considered variables turned out to be statistically significant. The signs of the parameter estimate for these variables are in line with expectations. The results are consistent with findings of prior empirical works in the sense that they show that ratings are under influence of the macroeconomic fundamentals (particularly domestic) as well as political and institutional factors (as indicated by the significance of the Governance variable). The study finds a negative and statistically significant effect

\footnotetext{
${ }^{5}$ Short-run estimates of parameters are available upon request.
} 
for past defaults, which is also in line with previous research, and points to a similar impact of countries' dependence on financial aid from official creditors. This may deepen countries' reluctance to use such assistance, including its precautionary forms targeted at countries with sound economic conditions and aimed at reinforcing their macro-financial position in times of heightened stress. Finally, the study's findings indicate that the condition of the banking system, which is proxied by the NPL variable, played an important role in the creditworthiness assessment of the EU countries in the period under analysis.

It is worth noting that the results presented in Table 7 are largely robust to a change of estimation technique, as suggested by the conclusions obtained with the use of an ordered probit model (cf. Appendix). All in all, as implied by the importance of the Assistance and the NPL variables, there is strong evidence supporting $\mathrm{H} 1$ hypothesis: "Next to the macroeconomic and institutional variables, the factors reflecting financial stability risk have additional explanatory power for sovereign ratings in the EU countries."

In the next step, in order to verify how the experience of the crisis changed the importance of individual variables in determining the country's rating and assess the durability of such changes (i.e. check whether there was a shift from crisis-related to post-crisis approach to sovereign creditworthiness assessment), the sample is divided into three subperiods:

1. pre-crisis period (2004-2007),

2. crisis period (2008-2012),

3. post-crisis period (2013-2018).

The demarcation between the first and the second subperiod is marked by the collapse of Lehman Brothers, which took place in 2008. The beginning of the third subperiod falls in 2013, when a permanent drop in tensions in the sovereign bond market in the EMU was already observed as a consequence of the announcement of the Outright Monetary Transactions (OMT) program by the ECB in the summer of 2012.

To check whether the division into three subperiods is reasonable, the Chow breakpoint test was conducted. Table 8 presents the results of testing.

Table 8. Results of testing stability of parameters

\begin{tabular}{|c|c|c|}
\hline Testing & $\begin{array}{c}\text { Structural break between } \\
\text { 1-st and 2-nd subperiod }\end{array}$ & $\begin{array}{c}\text { Structural break between } \\
\text { 2-nd and 3-rd subperiod }\end{array}$ \\
\hline Value of statistics & 2.433 & 2.533 \\
\hline$p$-value & 0.028 & 0.023 \\
\hline
\end{tabular}

Source: own calculations conducted in Stata.

The results from Table 8 indicate that the estimation of the parameters of the model for sub-samples is reasonable. Subperiods are relatively short and the number of years for each subperiod is low (from 4 to 6 ). Therefore, it is not justified to use panel cointegration techniques and the parameters of a simple panel regression model will be estimated. Table 9 contains the results of the estimation of the parameters of the panel regression model ${ }^{6}$. For

${ }^{6}$ Only the variables that turned out to be statistically significant in the main model and the variables available for all subperiods were used. 
each subperiod, the model assuming the presence of random effects turned out to be an optimal choice?.

Table 9. Results of the estimations of panel models with random effects for three subperiods

\begin{tabular}{|l|c|c|c|}
\hline \multicolumn{1}{|c|}{ Variable } & $\mathbf{2 0 0 4 - 2 0 0 7}$ & $\mathbf{2 0 0 8 - 2 0 1 2}$ & $\mathbf{2 0 1 3 - 2 0 1 8}$ \\
\hline GG debt & $-0.007(0.006)$ & $-0.028^{* * *}(0.004)$ & $-0.017^{* *}(0.008)$ \\
\hline Unemployment & $-0.121^{* * *}(0.015)$ & $-0.219^{* * *}(0.067)$ & $-0.128^{* * *}(0.038)$ \\
\hline GDP per capita & $0.003^{* * *}(0.001)$ & $0.001^{*}(0.001)$ & $0.001(0.002)$ \\
\hline Governance & $3.828^{* * *}(0.562)$ & $5.049^{* * *}(0.982)$ & $4.562^{* * *}(0.836)$ \\
\hline NPL & $-0.009(0.008)$ & $-0.103^{* * *}(0.021)$ & $-0.097^{* * *}(0.031)$ \\
\hline EA & $1.374^{* *}(0.681)$ & $-0.048^{*}(0.028)$ & $0.244^{*}(0.131)$ \\
\hline Model & Random effects & Random effects & Random effects \\
\hline p-value of the Hausman test & $\mathbf{0 . 2 7 8}$ & $\mathbf{0 . 2 1 7}$ & $\mathbf{0 . 3 5 4}$ \\
\hline
\end{tabular}

Robust standard errors in parentheses.

a Binary variable adopting the value of 1 if a given country is a euro area member state; 0 otherwise.

Source: own calculations conducted in Stata.

The results clearly indicate a change in the relevance of individual variables between the first and second subperiods, which - under different research assumptions - was previously found by Reusens and Croux (2017). One can also notice differences between the second and third subperiods, although these are less pronounced. Detailed assessment of the results allows us to formulate three main conclusions.

First, starting with the macroeconomic factors, a strong increase in the significance of the GG debt variable in the second subperiod deserves particular attention. During the crisis, the vast majority of EU countries recorded a sharp deterioration in the condition of the public finance sector. Over the fears of debt sustainability, some of them even lost access to market-based sources of financing and were forced to seek EU- and IMF-organized bailouts. This finding may also support the "wake-up call" contagion, i.e. an increased sensitivity to macroeconomic fundamentals in the pricing of sovereign risk observed after the start of the European debt crisis (cf. Beirne \& Fratzscher, 2013; Giordano, Pericoli, \& Tommasino, 2013). During the third subperiod, the role of macroeconomic factors somewhat decreased.

Second, an increase in the importance of the Governance variable during the crisis is noteworthy. The variable also remains more relevant in the third subperiod when compared to pre-crisis years. In a study on country default risk conducted for a group of euro area countries, which uses government bond yield spreads as the dependent variable, Boysen-Hogrefe (2017) shows that after the announcement of the OMT program the quality of governance has gained in importance with regard to other possible determinants of spreads, including the debt-to-GDP ratio. The author argues that since that announcement "financial markets have become more concerned about the willingness and capability to cooperate with the institutions that conduct the adjustment programs". The willingness and capability are, in turn, linked to different dimensions of governance. It can be assumed that CRAs also became more sensitive to the quality of governance, which they assessed as crucial for undertaking anti-crisis measures at the euro area/EU level. The fact that the

\footnotetext{
${ }^{7}$ Results of testing presence of effects are available on request.
} 
reforms aimed at safeguarding macro-financial stability in the future are not yet completed (like the banking union project) may be one of the explanations for why the importance of the Governance variable also remains high in the third subperiod.

Third, the condition of the banking sector seems to have gained importance in determining a country's rating after 2007 . The crisis has demonstrated that the costs of bank bailouts with the use of public funds are huge and can undermine the sustainability of public finances, particularly in bank-based financial systems like the ones in the EU countries. And despite the fact that the bail-in regime recently introduced by the EU aims at reducing the costs of bank bailouts for taxpayers, there are concerns that it can only prove itself in a one-off failure. In case of a systemic banking crisis, bail-in of private investors can add to a financial panic instead (cf. Avgouleas \& Goodhart, 2015). It appears, therefore, that the experience of a negative feedback loop between banks and sovereigns, unfinished reforms aimed at weakening the links between these two sectors, as well as persistent risks to banking sector stability such as the problem of NPLs (but also home bias in banks' sovereign portfolio) may explain still high relevance of the considered variable in the third subperiod. All in all, the findings strongly support $\mathrm{H} 2$ hypothesis about an increase in the role of banking sector stability in explaining the sovereign ratings of the EU countries after the outbreak of the crisis.

Finally, the role of the euro area member status in explaining ratings in the specified subperiods was checked. For this purpose, a binary variable EA was created. The variable adopts the value of 1 if a given country is a euro area member state and 0 otherwise. Analysis of the results (Table 9) allows us to indicate clear differences between individual subperiods. It seems that in the pre-crisis years the euro area countries derived additional benefits in terms of perceived credibility from the mere fact of holding the status of EMU members. It might have been due to the fact that the euro area was then perceived as an "elite club" of developed European economies. The monetary policy was transferred to the level of the ECB, which was supposed to build upon the Bundesbank's impeccable record of maintaining price stability, and the rest of the euro area countries experienced economic benefits (like lower interest rates) through the deepening of integration with Germany. That way, and amid the Great Moderation period, the risks associated with investing in the euro area, including the analysed countries, could have been under-priced (cf. Bernoth \& Erdogan, 2012; Oliveira, Curto, \& Nunes, 2012).

During the crisis, a switch from a positive to a negative effect of euro area member status is identified, which supports the previous findings of Reusens and Croux (2017). This is very likely to reflect the fact that the crisis revealed many "flaws" in the institutional architecture of the EMU, especially related to its financial safety net. These encompassed, among others, a failure to entrust the ECB with the role of a lender of last resort (LOLR), the lack of a banking union, including above all the supranational mechanism of bank resolution, and the absence of risk-sharing mechanisms such as the laterestablished European Stability Mechanism (ESM) (cf. Navaretti, Calzolari, \& Pozzolo, 2016). Under such conditions, contagion phenomena were observed within the euro area, which exacerbated the crisis and put the single currency project into question. In the post-crisis period, there is a return to a positive effect of euro area membership, which supports $\mathrm{H} 3$ hypothesis. At the same time, this effect is definitely weaker than before the crisis. This result may indicate a gradual return of confidence in the euro area 
after it addressed some of its "architectural deficiencies". In particular, the ECB become the LOLR with the announcement of the OMT programme, and the banking union had its promising start with the creation of the Single Supervisory Mechanism and the Single Resolution Mechanism in 2014 and 2016, respectively.

This study's findings suggest several policy implications. Regarding the euro area, these implications especially pertain to high stocks of NPLs which, despite a reduction observed in recent years, remain a challenge in some countries. The high levels of NPLs can considerably weigh on banks' performance and undermine future economic growth (Balgova, Nies, \& Plekhanov, 2016) ${ }^{8}$. Nonetheless, in the EMU, insufficient improvement in tackling the problem of NPLs might additionally revive self-fulfilling fears over the "doom loop" between banks and sovereigns. Compounding factors, particularly evident in the so-called peripheral EMU countries, are high public debt ratios and home bias in banks' sovereign debt holdings (cf. Altavilla, Pagano, \& Simonelli, 2017). Therefore, it is very important to continue with reforms initiated during the crisis, aimed at strengthening financial stability in the EMU. In a deeply integrated area where financial systems are highly interconnected, a coordinated approach to the problem of NPLs and other potential triggers of the loop is required. Proposals to delink banks from sovereigns include: completing the banking union by establishing the European Deposit Insurance Scheme, restricting the principle of zero-risk weight for sovereign exposures, and creating a "safe asset" for the euro area. All of these measures are likely to encounter political hurdles, hence the greater role for governance understood as readiness and willingness to cooperate.

For non-euro area countries, this study's findings might contribute to the long-running debate on the costs and benefits of their potential participation in the single currency project. The findings suggest that-apart from the crisis period-having non-euroarea status worked to the disadvantage of the country's creditworthiness assessment. This might come as surprising especially in the post-crisis years, given the fact that at that time, on average, these countries dealt relatively better in terms of macroeconomic fundamentals. Nevertheless, with many reservations regarding the incompleteness of reforms undertaken since the crisis, the euro area made progress in strengthening its financial safety net. The non-euro area countries have been included only in some initiatives and only to a limited extent (e.g., opting into the banking union before the euro adoption). However, they cannot take advantage of the rest of the net's elements. The recent proposal of the Eurogroup to establish Pandemic Crisis Support based on the ESM's Enhanced Conditions Credit Line can serve as an example (Eurogroup, 2020). Unlike what was experienced during the height of the euro area crisis, the conditionality attached would be limited. Due to the highest credit assessments assigned to the ESM, the members of the EMU would gain access to liquidity at very low-interest rates. It seems, therefore, that especially the lower-rated, non-euro area countries are worse off not having access to such instruments, which takes on special importance in the face of projected contraction in economic activity and challenges for public finances across the globe.

${ }^{8}$ Quoted in (Boumparis et al., 2019, p. 313). 


\section{CONCLUSIONS}

In this paper, the determinants of the EU countries' sovereign credit ratings have been studied. The analysis was conducted for the period from 2004 to 2018, which was later divided into pre-crisis, crisis, and post-crisis subperiods. The main research method used was the panel error correction model.

The empirical findings show that the role of individual credit rating determinants differed in the distinguished subperiods. In particular, the condition of the banking sector seems to have gained in importance after the outbreak of the euro area crisis and remained high in the post-crisis years. This most likely derives from the experience of a negative feedback loop between banks and sovereigns, which largely characterized the crisis, especially in the euro area, and its legacy in the form of macroeconomic imbalances (mainly fiscal) and persistent risks in the banking sector (such as the problems of NPLs and home bias). That is why it is so important to continue the reforms initiated during the crisis at the EU/euro area level and aimed at reducing the interdependence between the two sectors.

The study also shows that the status of being a euro area member exerts an impact on the country's creditworthiness assessment. Its effect switched from positive to negative during the crisis. In the post-crisis period, when euro redenomination risk had become a thing of the past and the EMU had emerged from the crisis institutionally stronger, euro area countries again began to reap additional benefits in terms of their credibility assessment from the mere fact of using the common currency. The opposite conclusions have been drawn for non-euro area EU members. It seems therefore that these countries are not necessarily better off staying on the side-lines of the European integration process, at least when it comes to their perceived default risk.

It would be worth conducting a similar study in the future when longer time series are available. The use of higher-frequency (i.e., quarterly) data should also be considered, which would improve the precision of the estimates. Ongoing monitoring of the situation in the euro area is particularly important for countries outside the single currency, which are still analysing the costs and benefits of (potential) future membership.

\section{REFERENCES}

Afonso, A. (2003). Understanding the determinants of sovereign debt ratings: Evidence for the two leading agencies. Journal of Economics and Finance, 27(1), 56-74. https://doi.org/https://doi.org/10.1007/bf02751590

Afonso, A., Gomes, P., \& Rother, P. (2010). Short- and long-run determinants of sovereign debt credit ratings. International Journal of Finance \& Economics, 16(1), 1-15. https://doi.org/10.1002/ijfe.416

Aktug, R., Nayar, N., \& Vasconcellos, G. (2013). Is sovereign risk related to the banking sector?. Global Finance Journal, 24(3), 222-249. https://doi.org/10.1016/j.gfj.2013.10.001

Altavilla, C., Pagano, M., \& Simonelli, S. (2017). Bank Exposures and Sovereign Stress Transmission. Review of Finance, 21(6), 2103-2139. https://doi.org/10.1093/rof/rfx038

Amstad, M., \& Packer, F. (2015). Sovereign ratings of advanced and emerging economies after the crisis. BIS Quarterly Review. Retrieved from https://www.bis.org/publ/qtrpdf/r_qt1512h.htm on October 21, 2019. 
Avgouleas, E., \& Goodhart, C. (2015). Critical Reflections on Bank Bail-ins. Journal of Financial Regulation, 1(1), 3-29. https://doi.org/10.1093/jfr/fju009

Ballester, L., \& González-Urteaga, A. (2017). How credit ratings affect sovereign credit risk: Crossborder evidence in Latin American emerging markets. Emerging Markets Review, 30, 200-214. https://doi.org/10.1016/j.ememar.2016.09.004

Beirne, J., \& Fratzscher, M. (2013). The pricing of sovereign risk and contagion during the European sovereign debt crisis. Journal of International Money and Finance, 34, 60-82. https://doi.org/10.1016/j.jimonfin.2012.11.004

Bernoth, K., \& Erdogan, B. (2012). Sovereign bond yield spreads: A time-varying coefficient approach. Journal of International Money and Finance, 31(3), 639-656. https://doi.org/10.1016/j.jimonfin.2011.10.006

Bissoondoyal-Bheenick, E. (2005). An analysis of the determinants of sovereign ratings. Global Finance Journal, 15(3), 251-280. https://doi.org/10.1016/j.gfj.2004.03.004

Boumparis, P., Milas, C., \& Panagiotidis, T. (2017). Economic policy uncertainty and sovereign credit rating decisions: Panel quantile evidence for the Eurozone. Journal of International Money and Finance, 79, 39-71. https://doi.org/10.1016/j.jimonfin.2017.08.007

Boumparis, P., Milas, C., \& Panagiotidis, T. (2019). Non-performing loans and sovereign credit ratings. International Review of Financial Analysis, 64, 301-314. https://doi.org/10.1016/j.irfa.2019.06.002

Boysen-Hogrefe, J. (2017). Risk assessment on euro area government bond markets - The role of governance. Journal of International Money and Finance, 73, 104-117. https://doi.org/10.1016/j.jimonfin.2017.01.005

Brůha, J., \& Kočenda, E. (2018). Financial stability in Europe: Banking and sovereign risk. Journal of Financial Stability, 36, 305-321. https://doi.org/10.1016/j.jfs.2018.03.001

Cantor, R., \& Packer, F. (1996). Determinants and Impact of Sovereign Credit Ratings. Economic Policy Review, 2(2). https://doi.org/10.2139/ssrn.1028774

Charemza, W., \& Deadman, D. (1997). Nowa ekonometria. Warszawa: Polskie Wydawnictwo Ekonomiczne.

Chari, A., Garcés, F., Martínez, J., \& Valenzuela, P. (2019). Sovereign Credit Risk, Financial Fragility, and Global Factors. Retrieved from http://www.up.edu.pe/UP_Landing/conference-financialstability-sustainability/documents/Valenzuela-Paper.pdf on March 20, 2020.

Chodnicka-Jaworska, P. (2015). Credit Rating Determinants for European Countries. Global Journal of Management and Business Research, 15(9).

Christopher, R., Kim, S., \& Wu, E. (2012). Do sovereign credit ratings influence regional stock and bond market interdependencies in emerging countries?. Journal of International Financial Markets, Institutions and Money, 22(4), 1070-1089. https://doi.org/10.1016/j.intfin.2012.01.003

Connolly, M. (2007). Measuring the Effect of Corruption on Sovereign Bond Ratings. Journal of Economic Policy Reform, 10(4), 309-323. https://doi.org/10.1080/17487870701552053

De Moor, L., Luitel, P., Sercu, P., \& Vanpée, R. (2018). Subjectivity in sovereign credit ratings. Journal of Banking \& Finance, 88, 366-392. https://doi.org/10.1016/j.jbankfin.2017.12.014

ECB (2019). Communication on supervisory coverage expectations for NPEs. Retrieved from https://www.bankingsupervision.europa.eu/press/letterstobanks/shared/pdf/2019/ssm.supe rvisory_coverage_expectations_for_NPEs_201908.en.pdf on December 19, 2019.

Erdem, O., \& Varli, Y. (2014). Understanding the sovereign credit ratings of emerging markets. Emerging Markets Review, 20, 42-57. https://doi.org/10.1016/j.ememar.2014.05.004 
Eurogroup (2020). Report on the comprehensive economic policy response to the COVID-19 pandemic. Retrieved from https://www.consilium.europa.eu/en/press/press-releases/2020/04/09/reporton-the-comprehensive-economic-policy-response-to-the-covid-19-pandemic/ on April 12, 2020.

Gande, A., \& Parsley, D. (2005). News spillovers in the sovereign debt market. Journal of Financial Economics, 75(3), 691-734. https://doi.org/10.1016/j.jfineco.2003.11.003

Giordano, R., Pericoli, M., \& Tommasino, P. (2013). Pure or Wake-up-Call Contagion? Another Look at the EMU Sovereign Debt Crisis. International Finance, 16(2), 131-160. https://doi.org/10.1111/j.1468-2362.2013.12033.x

Gültekin-Karakaş, D., Hisarcıklılar, M., \& Öztürk, H. (2011). Sovereign Risk Ratings: Biased Toward Developed Countries?. Emerging Markets Finance and Trade, 47(sup2), 69-87. https://doi.org/10.2753/ree1540-496x4703s204

Luitel, P., Vanpée, R., \& De Moor, L. (2016). Pernicious effects: How the credit rating agencies disadvantage emerging markets. Research in International Business and Finance, 38, 286-298. https://doi.org/10.1016/j.ribaf.2016.04.009

Mellios, C., \& Paget-Blanc, E. (2006). Which factors determine sovereign credit ratings?. The European Journal of Finance, 12(4), 361-377. https://doi.org/10.1080/13518470500377406

Monfort, B., \& Mulder, C. (2000). Using Credit Ratings for Capital. Requirements on Lending to Emerging. Market Economies: Possible Impact of a New Basel Accord (IMF Working Paper, 00/69). Retrieved from https://www.imf.org/en/Publications/WP/Issues/2016/12/30/UsingCredit-Ratings-for-Capital-Requirementson-Lending-to-Emerging-Market-Economies-Possible3526 on November 21, 2019.

Montes, G., \& de Oliveira, D. (2016). Beyond the macroeconomic determinants of sovereign credit ratings in developing economies: a panel data analysis considering different dimensions. Retrieved from https://www.anpec.org.br/encontro/2015/submissao/files_l/i44bb778240c44a3de16bb2e82fd73a4a4.pdf on November 21, 2019.

Navaretti, G., Calzolari, G., \& Pozzolo, A. (2016). Diabolic Loop or Incomplete Union? Sovereign and Banking Risk. Retrieved from https://european-economy.eu/2016-1/diabolic-loop-orincomplete-union-sovereign-and-banking-risk/ on December 15, 2019.

Oliveira, L., Curto, J., \& Nunes, J. (2012). The determinants of sovereign credit spread changes in the Euro-zone. Journal of International Financial Markets, Institutions and Money, 22(2), 278-304. https://doi.org/10.1016/j.intfin.2011.09.007

Ozturk, H. (2014). The Origin of Bias in Sovereign Credit Ratings: Reconciling Agency Views with Institutional Quality. The Journal of Developing Areas, 48(4), 161-188. https://doi.org/10.1353/jda.2014.0066

Pesaran, M. (2004). General Diagnostic Tests for Cross Section Dependence in Panels (IZA Discussion Paper No. 1240). Retrieved from http://ftp.iza.org/dp1240.pdf on April 4, 2020.

Pesaran, M. (2007). A simple panel unit root test in the presence of cross-section dependence. Journal of Applied Econometrics, 22(2), 265-312. https://doi.org/10.1002/jae.951

Ramlall, I. (2016). Does Central Bank Quality Determine Sovereign Ratings and Credit Default Swap Spreads: Evidence from the World?. Journal of Central Banking Theory and Practice, 5(3), 5-29. https://doi.org/10.1515/jcbtp-2016-0017

Reinhart, C. (2002). Sovereign Credit Ratings Before and After Financial Crises. In R. Levich, G. Majnoni, \& C. Reinhart, Ratings, Rating Agencies and the Global Financial System. New York: Springer.

Reusens, P., \& Croux, C. (2017). Sovereign credit rating determinants: A comparison before and after the European debt crisis. Journal of Banking \& Finance, 77, 108-121. https://doi.org/10.1016/j.jbankfin.2017.01.006 
Sehgal, S., Mathur, S., Arora, M., \& Gupta, L. (2018). Sovereign ratings: Determinants and policy implications for India. IIMB Management Review, 30(2), 140-159. https://doi.org/10.1016/j.iimb.2018.01.006

Soudis, D. (2016). Determinants of Sovereign Bonds Ratings: A Robustness Analysis. Bulletin of Economic Research, 69(2), 164-177. https://doi.org/10.1111/boer.12093

Teixeira, J., Silva, F., Ferreira, M., \& Vieira, J. (2018). Sovereign credit rating determinants under financial crises. Global Finance Journal, 36, 1-13. https://doi.org/10.1016/j.gfj.2018.01.003

Tennant, D., Tracey, M., \& King, D. (2020). Sovereign credit rating: Evidence of bias against poor countries. The North American Journal of Economics and Finance, 51, 100877. https://doi.org/10.1016/j.najef.2018.11.006https://doi.org/

Westerlund, J. (2007). Testing for Error Correction in Panel Data. Oxford Bulletin of Economics and Statistics, 69(6), 709-748. https://doi.org/10.1111/j.1468-0084.2007.00477.x

Yalta, A., \& Yalta, A. (2018). Are credit rating agencies regionally biased?. Economic Systems, 42(4), 682-694. https://doi.org/10.1016/j.ecosys.2018.08.001 


\section{Appendix:}

As a robustness check, variables associated with credit ratings were treated as an ordered one ${ }^{9}$ and the parameters of an ordered probit model were estimated.

$$
\begin{gathered}
R A T_{i t}^{*}=\boldsymbol{\beta}^{T} \boldsymbol{x}_{i t}+\varepsilon_{i t}, \\
R A T_{i}=2 *\left\{R A T_{i t}^{*}>\mu_{3}\right\}+\left\{\mu_{3} \geq R A T_{i t}^{*}>\mu_{2}\right\}-\left\{R A T_{i t}^{*} \leq \mu_{1}\right\}, \\
\varepsilon_{i t} \sim N(0,1),
\end{gathered}
$$

In the model (A.1)-(A.3) the variable associated with credit rating is treated as discrete, ordered variable. It takes the following 4 values:

-1 - in the case of highly speculative, substantial risk, extremely speculative or default grade ( $\mathrm{B}+$ or lower),

0 - in the case of non-investment speculative grade (between BB- and $B B+$ ),

1 - in the case of lower medium investment grade (between BBB- and BBB+),

2 - in the case of upper medium, high or prime investment grade ( $A$ - or higher)

Results of the estimation of the parameters of the model (A.1)-(A.3) are presented in Table A. 1.

Table A.1. Results of the estimation of the parameters of the ordered probit model

\begin{tabular}{|l|c|}
\hline \multicolumn{1}{|c|}{ Variable } & Estimate \\
\hline GDP per capita & $0.012^{* * *}(0.003)$ \\
\hline Unemployment & $-0.005(0.830)$ \\
\hline Assistance & $-1.389^{* * *}(0.175)$ \\
\hline Default history & $-0.698^{*}(0.398)$ \\
\hline GG debt & $-0.019^{* * *}(0.002)$ \\
\hline NPL & $-0.144^{* * *}(0.025)$ \\
\hline Governance & $1.990^{* * *}(0.236)$ \\
\hline$\mu_{1}$ & -2.319 \\
\hline$\mu_{2}$ & 0.033 \\
\hline$\mu_{3}$ & 2.342 \\
\hline
\end{tabular}

$*, * *, * * *$ indicate statistical significance at the $0.1,0.05$, and 0.01 level, respectively.

Source: own calculations conducted in Stata.

The results indicate that most of the variables, which were found to have explanatory power for sovereign ratings in the cointegrating relation, turned out to have a significant impact in an ordered discrete choice model. The only exception is the Unemployment variable, whose statistical significance was found only in the main model. All in all, the obtained results largely confirm the validity of the main model, presented in Table 7.

${ }^{9}$ The rating of a particular year is the rating attributed at 31st December of that year. 


\section{Author}

\section{Ewa Stawasz-Grabowska}

$\mathrm{PhD}$ in Finance (University of Lodz); Master in International Economics (University of Lodz). Her research interests concentrate mainly on monetary and financial policy in the euro area. Correspondence to: Ewa Stawasz-Grabowska, PhD, University of Lodz, Faculty of Economics and Sociology, 90-255 Lodz, 3/5 POW Street, Poland, e-mail: ewa.grabowska@uni.lodz.pl ORCID (1) http://orcid.org/0000-0002-2456-552X

\section{Acknowledgements and Financial Disclosure}

The article came into being within the project no. 2015/17/N/HS4/02921 financed by National Science Centre, Poland.

I am grateful to the anonymous reviewers for providing helpful comments and suggestions.

\section{Copyright and License}

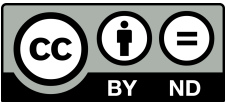

This article is published under the terms of the Creative Commons Attribution - NoDerivs (CC BY-ND 4.0) License http://creativecommons.org/licenses/by-nd/4.0/

Published by the Centre for Strategic and International Entrepreneurship - Krakow, Poland 
